\title{
THE INFLUENCE OF ONLINE SERVICES AND PROMOTIONS TO PURCHASHING DECISION OF ECONOMIC RAILWAY TRANSPORTATION IN SUMATERA SELATAN
}

\author{
Mujari \\ STIE Serelo Lahat \\ mujari292726@gmail.com
}

\begin{abstract}
PT. Kereta Api Indonesia (Persero) or later called PT. KAI is one of transportation company which provide railway transport services in order to facilitate the displacement people and goods. PT KAI use internet technology to provide online ticketing system. This innovation with online system must be supported by good promotion to increase the purchasing decicion of railway transportation. This studi aims to determine the effect of online services and promotions to purchasing decicion of economic railway transportation in Sumatera Selatan. This study uses asosiatif research method with questionnaire. Samples are 100 passengers chosen by accidental sampling technique. The analysis used is multiple linier regression. The result shows that online system did not influence the purchashing decicion of railwal ticket, hence promotion did influence the purchasing decicion. Based on the result, the main reason of purchasing railway ticket in Sumatera Selatan are a word of mouth and formal promotions. To increase the custumer numbers, PT. KAI must give better innovation on online system so they can compete in the market.
\end{abstract}

Keywords: Online system services, PT KAI Sumatera Selatan Region, Promotion, Purchasing Decision

\section{PENGARUH LAYANAN ONLINE DAN PROMOSI TERHADAP KEPUTUSAN PEMBELIAN TRANSPORTASI KERETA API EKONOMI DI SUMATERA SELATAN}

\author{
Mujari \\ Sekolah Tinggi Ilmu Ekonomi Serelo Lahat \\ mujari292726@gmail.com
}

\begin{abstract}
ABSTRAK
PT. Kereta Api Indonesia (Persero) atau PT. KAI merupakan salah satu perusahaan yang menyediakan jasa transportasi kereta api untuk angkutan penumpang dan barang. PT KAI memanfaatkan teknologi internet dengan menawarkan sistem pemesanan tiket secara online. Inovasi layanan dengan sistem online ini tentunya juga harus didukung dengan kegiatan promosi yang baik untuk meningkatkan keputusan konsumen dalam menggunakan jasa kereta api. Penelitian ini bertujuan untuk mengetahui pengarus pelayanan sistem online dan promosi terhadap keputusan pembelian tiket kereta api ekonomi di Sumatera Selatan. Jenis penelitian yang
\end{abstract}


digunakan adalah penelitian asosiatif dengan pengumpulan data menggunakan kuisioner. Sampel penelitian ini adalah sebanyak 100 orang penumpang yang dipilih menggunkan metode accidental sampling. Teknik analisis data menggunakan analisis regresi linier berganda. Hasil penelitian menunjukkan bahwa pelayanan sistem online tidak berpengaruh signifikan terhadap keputusan pembelian, sedangkan variabel promosi berpengaruh positif signifikan terhadap keputusan pembelian. Hal ini menunjukkan bahwa alasan utama masyarakat dalam memilih transportasi kereta api di Sumatera Selatan masih dipengaruhi oleh kegiatan promosi baik itu secara mulut ke mulut maupun secara formal. Untuk menarik minat pelanggan baru, PT KAI harus senantiasa melakukan inovasi pelayanan sistem online agar dapat bersaing di pasar.

Kata Kunci: Pelayanan sistem online, PT KAI Wilayah Sumatera Selatan, Promosi, Keputusan Pembelian.

\section{PENDAHULUAN}

Transportasi adalah sebuah sarana umum yang apapun jenisnya dan dimanapun tempatnya, sangat diperlukan bagi setiap orang yang hendak bepergian, apalagi ke tempat yang tidak mungkin untuk dijangkau hanya dengan berjalan kaki. Perekonomian yang semakin berkembang ke arah globalisasi membutuhkan mobilisasi yang tinggi, sehingga masyarakat akan semakin jeli dalam memilih sarana transportasi yang digunakan (Wardhana dan Kartawinata, 2016).

Perusahaan yang bergerak di bidang jasa harus memilih strategi pemasaran yang tepat untuk menarik minat konsumen dalam menggunakan jasa yang mereka tawarkan. Salah satu faktor penting dalam strategi pemasaran adalah promosi. Berkembangnya penggunaan internet saat ini juga mengharuskan perusahaan transportasi untuk ikut melakukan inovasi dengan menawarkan pelayanan sistem online. Menurut Kotler (2012), keputusan pembelian online dipengaruhi oleh empat hal yaitu sikap, kepercayaan, pembelajaran, dan pengalaman belanja di masa lalu. Penelitian ini membatasi keputusan pembelian online yang dipengaruhi pada pembelajaran karena berhubungan dengan informasi yang diberikan melalui kegiatan promosi oleh perusahaan. Penumpang yang ingin melakukan pembelian online akan melakukan pembelajaran dan mencari informasi dari berbagai sumber.

Sumardi (2009) menyatakan bahwa konsumen lebih percaya pada informasi dari mulut ke mulut daripada metode promosi apapun yang sifatnya formal. Karena itulah, kualitas pelayanan dan promosi merupakan dua faktor yang tidak bisa dipisahkan dalam menentukan keputusan pembelian pelanggan.

Menurut Jati (2012 :150) Beberapa keuntungan yang didapatkan dalam penggunaan aplikasi pelayanan Online adalah: 1) Proses pelayanan sistem online dapat dilakukan dari mana saja dan kapan saja; 2) Data yang transparan langsung dari website; 3) Proses reservasi langsung; 4) Dapat 
mencetak tiket sendiri dan dapat langsung digunakan; 5)Pembayaran melalui transfer bank, sehingga lebih cepat dan akurat.

PT. Kereta Api Indonesia (Persero) merupakan salah satu perusahaan yang menyediakan jasa transportasi kereta api untuk angkutan penumpang dan barang. PT KAI ikut memanfaatkan perkembangan teknologi internet dengan menyediakan layanan pemesanan tiket secara online. Sistem ini mulai dijalankan sejak tahun 2012 dan terus ditingkatkan kualitasnya hingga saat ini. Inovasi terbarunya yaitu produk Rail Ticketing System (RTS) next Generation yang diluncurkan pada bulan September 2016, bertepatan dengan ulang tahun PT KAI ke-71. RTS next generation ini merupakan sistem pemesanan tiket secara online dan telah dikembangkan dengan penambahan fitur pemesanan makanan restorasi PT Reska Multi Usaha (RMU). Pemesanan online bisa dilakukan 90 hari sebelum keberangkatan dan dapat dipesan melalui webside (tiket.kai.id) maupun melalui aplikasi mobile.

Tabel 1 di bawah ini menunjukkan data yang dikeluarkan oleh Badan Pusat Statistik mengenai jumlah penumpang kereta api di Sumatera selama 5 tahun terakhir. Berdasarkan data tersebut dilihat bahwa jumlah penumpang kereta api di Sumatera mengalami pertumbuhan yang cukup tinggi walaupun sempat mengalami penurunan di tahun 2013 . Dari total penumpang di Sumatera, kurang lebih $30 \%$ merupakan penumpang dari daerah Sumatera Selatan.

Tabel 1

Data Jumlah Penumpang Kereta Api di Sumatera Tahun 2012-2016

(dalam juta jiwa)

\begin{tabular}{l|l}
\hline Tahun & Jumlah Penumpang \\
\hline 2012 & 4.384 \\
\hline 2013 & 3.995 \\
\hline 2014 & 4.904 \\
\hline 2015 & 5.324 \\
\hline 2016 & 5.981 \\
\hline
\end{tabular}

Sumber : Badan Pusat Statistik 2017

Jasa Transportasi Kereta Api Ekonomi di Wilayah Sumatera Selatan masih diminati masyarakat di tengah bersaingnya sarana transportasi lain seperti angkutan travel karena harganya yang relatif murah. Selain itu, kereta api juga merupakan sarana transportasi penting dalam mengantarkan penumpang dengan jumlah besar sebagaimana yang dimuat dalam Undang-Undang No. 23 tahun 2007 tentang Perkeretaapian.

Berdasarkan penelitian yang dilakukan oleh Duari, 2014 menunjukkan bahwa bauran pemasaran berupa produk, tempat, harga, dan promosi berpengaruh signifikan terhadap keputusan pembelian. Hasil lain ditunjukkan oleh penelitian Wasiun, Nugraha, dan Prabawani (2015) bahwa faktor yang paling mempengaruhi keputusan pembelian pelanggan adalah sistem pelayanan online.

Pembelian tiket kereta secara online dinilai lebih efisien karena mengurangi biaya pegawai penjualan tiket, mengurangi biaya cetak tiket 
secara konvensional, dan yang terutama adalah efisiensi waktu. Meskipun demikian, pelayanan sistem online ini juga memiliki beberapa kelemahan seperti terbatasnya akses internet di beberapa wilayah, terbatasnya promosi dari pihak PT. KAI, dan terbatasnya pengetahuan tentang cara pemesanan tiket secara online.

Dari semua hal di atas, penulis tertarik untuk mengetahui pengaruh pelayanan sistem online dan promosi terhadap keputusan pembelian tiket kereta api di Sumatera Selatan. Hal ini sesuai dengan penelitian Duari (2014) dan Wasiun, Nugraha, dan Prabawani (2015) yang menggabungkan kedua faktor tersebut. Berdasarkan permasalahan di atas, penulis dapat menuliskan tujuan penelitian sebagai berikut :

1. Untuk mengetahui dan menganalisa Pengaruh Pelayanan Sistem Online Terhadap Keputusan Pembelian Tiket Kereta Api Ekonomi di Wilayah Sumatera Selatan.

2. Untuk mengetahui dan menganalisa Pengaruh Promosi Terhadap Keputusan Pembelian Tiket Kereta Api Ekonomi di Wilayah Sumatera Selatan.

3. Untuk mengetahui dan menganalisa Pengaruh Pelayanan Sistem Online dan Promosi Terhadap Keputusan Pembelian Tiket Kereta Api Ekonomi di Wilayah Sumatera Selatan

Gambar 1

Peta Jalur Kereta Api Wilayah Sumatera Selatan

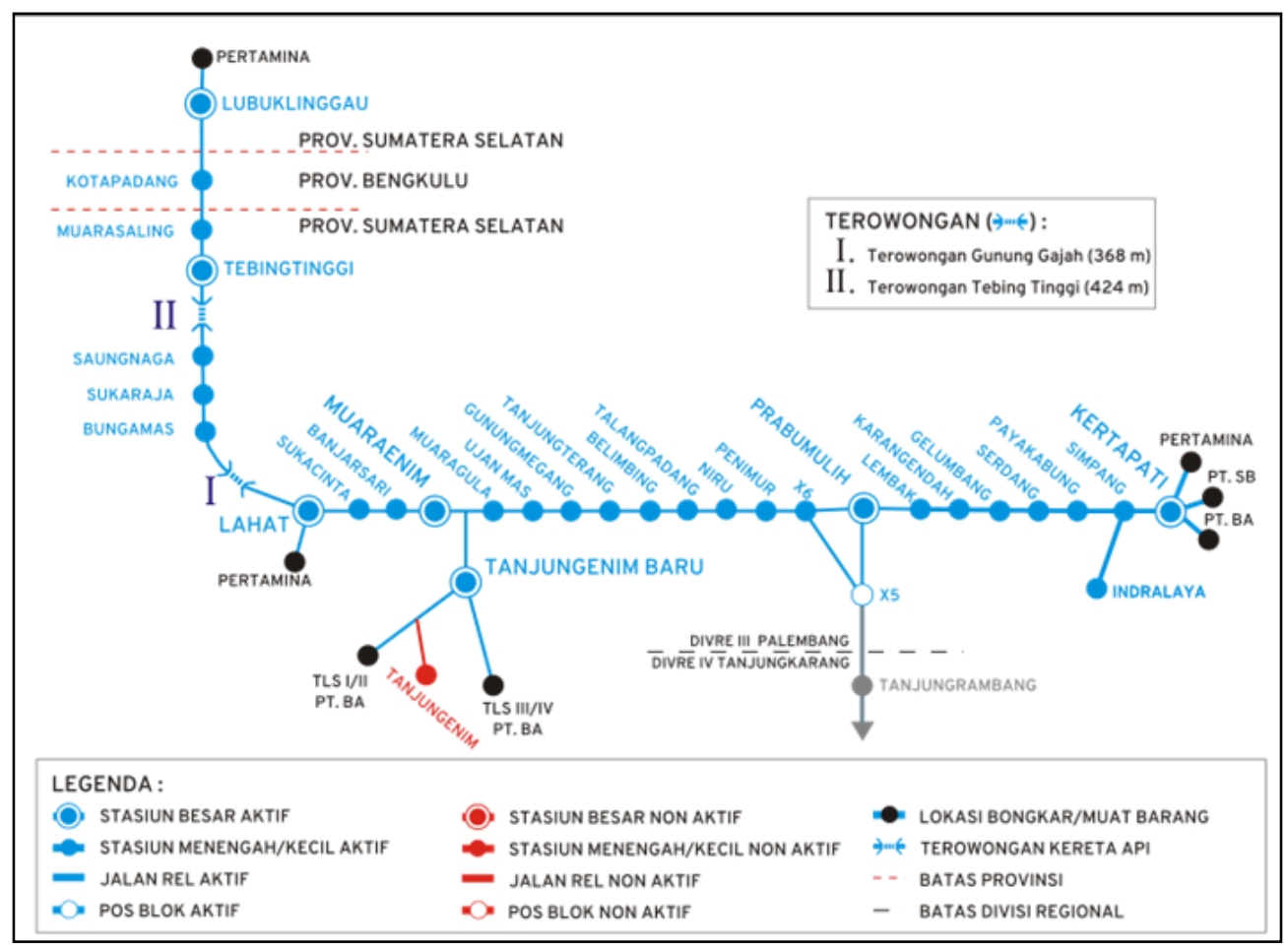

Sumber: PT KAI, 2017 


\section{METODE PENELITIAN}

Desain Penelitian ini merupakan penelitian asosiatif kausal dengan menggunakan pendekatan kuantitatif. Penelitian asosiatif kausal adalah penelitian yang bertujuan untuk mengetahui pengaruh antara dua variabel atau lebih (Sugiyono, 2013). Adapun yang menjadi populasi dalam penelitian ini yaitu pengguna jasa Kereta Api Ekonomi yang melakukan pembelian tiket secara online dengan relasi Lubuk Linggau - Kertapati khususnya keberangkatan dari Stasiun Lubuk Linggau, dari Stasiun Lahat, dan dari Stasiun Muara Enim.

Karena populasi dalam penelitian ini tidak diketahui jumlahnya, maka diasumsikan bahwa populasi tidak diketahui. Jadi sebuah sampel sebanyak 100 yang diambil dari populasi berjumlah 5.000 secara kasar mempunyai ketetapan estimasi yang sama dengan 100 sampel (Cooper dan Emory, 1996). Jadi untuk populasi yang tidak terdefinisikan secara pasti jumlah sampel ditentukan secara langsung sebesar 100 responden dengan rincian seperti pada tabel 2. Responden ditetapkan berdasarkan Accidental Sampling yaitu teknik penentuan responden berdasarkan kebetulan, yaitu siapa saja yang secara kebetulan bertemu dengan peneliti dapat digunakan sebagai sampel, dengan syarat melakukan pemesanan tiket kereta api secara online.

Tabel 2

Rincian Jumlah Responden

\begin{tabular}{|c|c|c|}
\hline No & $\begin{array}{c}\text { Stasiun } \\
\text { Keberangkatan }\end{array}$ & $\begin{array}{c}\text { Jumlah } \\
\text { (Responden) }\end{array}$ \\
\hline 1. & Lubuk Linggau & 40 \\
\hline 2. & Lahat & 30 \\
\hline 3. & Muara Enim & 30 \\
\hline & Total & 100 \\
\hline
\end{tabular}

Sumber : Data diolah

Pengumpulan data dilakukan dengan menggunakan kuisioner. Adapun penilaian dari instrument ini menurut skala likert ( Purwanto dan Sulistyastuti, 2016).

Variabel dalam penelitian ini ditentukan berdasarkan landasan teori yaitu pelayanan sistem online (X1), promosi (X2) dan keputusan pembelian (Y). Secara operasional variabel tersebut didefinisikan dapat dilihat pada tabel 3.

Analisis yang digunakan untuk mengetahui besarnya pengaruh pelayanan sistem online (X1), promosi (X2) dan keputusan pembelian (Y) adalah dengan analisis regresi linier berganda. 
Tabel 3

Definisi Operasional Variabel

\begin{tabular}{|c|c|c|c|}
\hline Variabel & Indikator & Deskripsi & Pertanyaan \\
\hline $\begin{array}{c}\text { Pelayanan } \\
\text { Sistem } \\
\text { Online } \\
\text { (X1) }\end{array}$ & 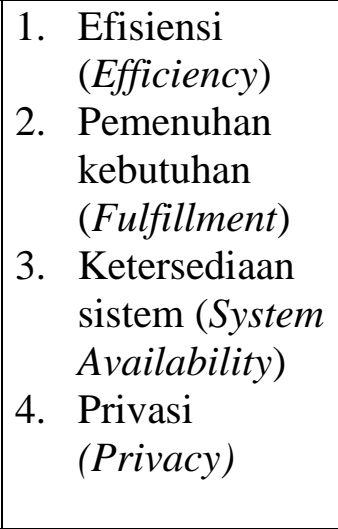 & $\begin{array}{l}\text { 1. Suatu ukuran keberhasilan yang } \\
\text { dinilai dari segi besarnya } \\
\text { sumber/biaya } \\
\text { 2. Keinginan terhadap benda/jasa dan } \\
\text { hal apapun yang dapat memberikan } \\
\text { kepuasan } \\
\text { 3. Tersedianya sistem yang baik dan } \\
\text { handal } \\
\text { 4. Kemampuan untuk } \\
\text { mempertahankan kehidupan dan } \\
\text { urusan personal dari publik }\end{array}$ & $\begin{array}{l}6-8 \\
9-10\end{array}$ \\
\hline $\begin{array}{l}\text { Promosi } \\
\text { (X2) }\end{array}$ & $\begin{array}{l}\text { 1. Informasi } \\
\text { 2. Konsumen } \\
\text { 3. Peningkatan } \\
\text { Penjualan } \\
\text { 4. Pembeda } \\
\text { 5. Citra } \\
\text { produk/jasa }\end{array}$ & $\begin{array}{l}\text { 1. Untuk menyebarkan informasi } \\
\text { produk atau jasa perusahaan } \\
\text { kepada pasar. } \\
\text { 2. Untuk memperoleh konsumen baru } \\
\text { dan menjaga kesetiaan dari } \\
\text { konsumen. Jadi konsumen tetap } \\
\text { setia untuk membeli dan } \\
\text { menggunakan produk atau jasa } \\
\text { perusahaan. } \\
\text { 3. Untuk meningkatkan penjualan } \\
\text { sehingga pendapatan perusahaan } \\
\text { meningkat. } \\
\text { 4. Untuk memberi pembeda dan } \\
\text { mengunggulkan } \\
\text { perusahaan dibanding dengan } \\
\text { produk para pesaing. } \\
\text { 5. Dan untuk membentuk citra } \\
\text { produk ataupun jasa dan nama } \\
\text { perusahaan dimata para konsumen. }\end{array}$ & $\begin{array}{l}5-6 \\
7-8\end{array}$ \\
\hline $\begin{array}{c}\text { Keputusan } \\
\text { pembelian } \\
\text { (Y) }\end{array}$ & $\begin{array}{l}\text { 1. Kemantapan } \\
\text { pada sebuah } \\
\text { produk. } \\
\text { 2. Kebiasaan } \\
\text { dalam membeli } \\
\text { produk. } \\
\text { 3. Memberikan } \\
\text { rekomendasi } \\
\text { kepada orang } \\
\text { lain. } \\
\text { 4. Melakukan } \\
\text { pembelian } \\
\text { ulang. }\end{array}$ & $\begin{array}{l}\text { 1. Tidak memilih produk yang lain } \\
\text { 2. Memilih dan menggunakan } \\
\text { produk dalam periode tertentu } \\
\text { 3. Memberikan saran ke orang } \\
\text { sekitar } \\
\text { 4. Menggunakan kembali produk } \\
\text { tersebut }\end{array}$ & $\begin{array}{c}1-4 \\
5-6 \\
7-8 \\
9-10\end{array}$ \\
\hline
\end{tabular}


REFERENSI: Jurnal Ilmu Manajemen dan Akuntansi Vol.5 No.2 Desember 2017

Uji instrumen dilakukan dengan melakukan uji validitas dan realibilitas kuisioner. Uji validitas dengan ketentuan jika memiliki nilai $\mathrm{r}$ (Corrected item Total correlation) $>0,300$ maka item dari sepuluh butir pertanyaan pada variabel tersebut adalah valid, dan jika memiliki nilai $\mathrm{r}$ (Corrected item - Total correlation) $<0,300$ maka item pertantaan adalah tidak valid (Arikunto, 2010). Pada uji reliabilitas dilakukan dengan menggunakan Alpha Cronbach's angka yang didapat melalui metode Alpha Cronbach's kemudian dibandingkan dengan Koefisien $(r)=0,600$ bila nilai Alpha Cronbach's lebih besar dari 0,600, maka variabel penelitian dikatakan reliable atau terpercaya.

Uji asumsi klasik yang digunakan dalam penelitian ini adalah uji nurmalitas dan linieritas data. Uji normalitas dilakukan untuk mengetahui normal tidaknya distribusi data, sedangkan uji linieritas ini dimaksud untuk mengetahui apakah model persamaan yang kita peroleh cocok atau tidak (Sudjana, 2010).

Persamaan umum regresinya yaitu:

$\mathrm{Y}=\mathrm{a}+\mathrm{b} 1 \mathrm{X} 1+\mathrm{b} 2 \mathrm{X} 2+\mathrm{e}$

Keterangan :

$\mathrm{Y}=$ Keputusan Pembelian

$\mathrm{a}=$ Konstanta $\mathrm{b} 1=$ Koefisien regresi untik X1

b2 $=$ Koefisien regresi untuk X2

$\mathrm{X} 1$ = Pelayanan sistem online

$\mathrm{X} 2$ = Promosi

$\mathrm{e}=$ eror

Uji signifikansi simultan (uji F) digunakan untuk menunjukkan apakah kriteria independen yang dimasukkan dalam model mempunyai pengaruh secara bersama-sama terhadap kriteria dependen (Ghozali, 2009). Pengujian dilakukan dengan tingkat signifikansi $0,05(5 \%)$. Pengujian hipotesis penelitian didasarkan pada kriteria pengambilan keputusan sebagai berikut:

a. Jika sig F-hitung < 0,05 maka Ha diterima, berarti kriteria independen secara keseluruhan atau bersamasama mempengaruhi kriteria dependen.

b. Jika sig F-hitung > 0,05 maka Ha ditolak, berarti kriteria independen secara keseluruhan atau bersamasama tidak mempengaruhi kriteria dependen.

Uji parsial atau uji-t akan digunakan untuk menguji pengaruh kriteria independen secara parsial terhadap kriteria dependen (Ghozali, 2011). Untuk menentukan nilai t-tabel, tingkat signifikan yang digunakan sebesar 5\% dengan derajat kebebasan (degree of freedom $) \mathrm{df}=(\mathrm{n}-2)$ dimana $\mathrm{n}$ adalah jumlah observasi, $\mathrm{k}$ adalah kriteria 
termasuk konstanta, dengan kriteria uji

yang digunakan adalah:

Tabel 4

Statistik Deskriptif

\begin{tabular}{|l|r|r|r|r|r|}
\hline & Minimum & Maximum & Mean & $\begin{array}{c}\text { Std. } \\
\text { Deviation }\end{array}$ & \multicolumn{1}{|c|}{$\mathrm{N}$} \\
\hline Predicted Value & 32.18 & 46.92 & 40.93 & 4.795 & 100 \\
Residual & -20.470 & 16.821 & .000 & 7.777 & 100 \\
Std. Predicted & -1.825 & 1.248 & .000 & 1.000 & 100 \\
Value & -2.605 & 2.141 & .000 & .990 & 100 \\
Std. Residual & & & & \\
\hline
\end{tabular}

Sumber: Hasil olah data

a. Bila t-hitung > t-tabel, maka Ho ditolak, Ha diterima, berarti ada pengaruh yang signifikan dari variabel independen terhadap variabel dependen.

b. Bila t-hitung < t-tabel, maka Ho diterima, Ha ditolak, berarti tidak ada pengaruh yang signifikan dari variabel independen terhadap variabel dependen.

\section{HASIL PENELITIAN}

Hasil tabel 4 di atas didapat nilai minimum sebesar 32.18 maximum sebesar 46.92 mean sebesar 40.93, standar deviasi sebesar 4.795 . Dari hasil analisis regresi berganda pada tabel 5 diperoleh model persamaan $\mathrm{Y}=22.273+0.122 \mathrm{X} 1+$ $0.373 \mathrm{X} 2+$ e. Persamaan tersebut menunjukkan adanya pengaruh yang positif antara variabel pelayanan sistem online dan promosi terhadap keputusan pembelian tiket kereta api di wiliayah Sumatera Selatan.

Nilai variabel Pelayanan Sistem Online (X1) sebesar 0.122 yang berarti jika variabel Pelayanan Sistem Online (X1) ditingkatkan sebesar 0.122 maka akan meningkatkan variabel Keputusan Pembelian (Y) sebesar 0.12 Nilai variabel Promosi (X2) sebesar 0.373 yang berarti jika variabel Promosi (X2) ditingkatkan sebesar 0.373 maka akan meningkatkan variabel Keputusan Pembelian (Y) sebesar 0.373 .

Hasil uji t menunjukkan bahwa pelayanan sistem online tidak berpengaruh signifikan terhadap keputusan pembelian karena nilai $\mathrm{p}$ yang dihasilkan lebih besar dari alpha 5\%. Variabel promosi berpengaruh positif signifikan terhadap keputusan pembelian karena nilai $p$ yang dihasilkan lebih kecil dari alpha 5\%. Tabel 5 juga menerangkan nilai koefesien diterminasi sebesar 0.275 atau $27,5 \%$ hal ini berarti variabel - 
variabel bebas mempunyai sumbangan terhadap variabel terikat sebesar $27 \%$ dan sisanya $63 \%$ dipengaruhi oleh faktor lain yang tidak diteliti oleh penulis.

Tabel 5

Hasil Olah Data SPSS

\begin{tabular}{|c|c|c|c|c|c|c|}
\hline \multicolumn{2}{|c|}{ Model } & \multicolumn{2}{|c|}{$\begin{array}{l}\text { Unstandardized } \\
\text { Coefficients }\end{array}$} & $\begin{array}{l}\text { Standardized } \\
\text { Coefficients }\end{array}$ & $\mathrm{t}$ & Sig. \\
\hline 1 & (Constant) & 22.273 & 3.296 & & 6.758 & .000 \\
\hline & $\begin{array}{l}\text { Sistem Pelayanan } \\
\text { Online }\end{array}$ & .122 & .099 & .13 & 1.232 & .221 \\
\hline & Promosi & .373 & .097 & .42 & 3.860 & .000 \\
\hline
\end{tabular}

a. Dependent Variable: Keputusan Pembelian

Model Summary

\begin{tabular}{|l|r|r|r|r|}
\hline Model & $\mathrm{R}$ & R Square & $\begin{array}{c}\text { Adjusted R } \\
\text { Square }\end{array}$ & $\begin{array}{c}\text { Std. Error of the } \\
\text { Estimate }\end{array}$ \\
\hline 1 & $.525^{\mathrm{a}}$ & .275 & .261 & 7.857 \\
\hline
\end{tabular}

a. Predictors: (Constant), Promosi, Sstem Pelayanan Online

c. Dependent Variable: Keputusan Pembelian

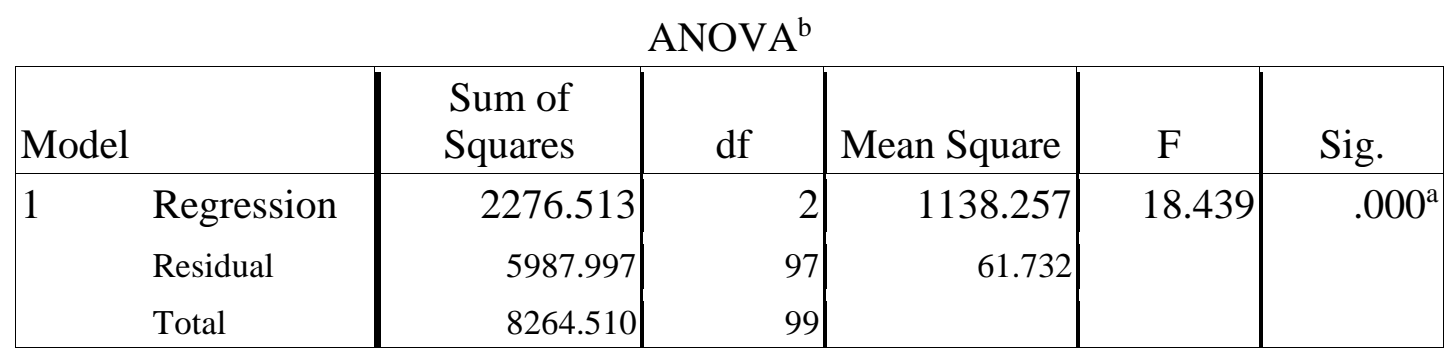

a. Predictors: (Constant), Promosi, Sstem Pelayanan Online

b. Dependent Variable: Keputusan Pembelian

Sumber : Hasil Olah Data

Hasil uji $F$ menjelaskan bahwa variabel Pelayanan Sistem Online $\left(\mathrm{X}_{1}\right)$, dan Promosi $\left(\mathrm{X}_{2}\right)$, berpengaruh signifikan secara bersama-sama terhadap variabel Keputusan Pembelian (Y).

\section{PEMBAHASAN}

Menurut Gustafsson dan Johnson (2003), untuk bisa bertahan dalam persaingan, perusahaan perlu melakukan pengembangan pelayanan. Hal ini bisa dilakukan dalam tiga 
tahapan, yaitu pemeliharaan, peningkatan performa layanan, dan inovasi layanan. Fokus pada tahap pemeliharaan adalah untuk memperbaiki kesalahan yang terjadi selama proses pelayanan. Setelah semua kesalahan diperbaiki, maka pada tahap sealnjutnya lakukan peningkatan kualitas pelayanan. Tahap terakhir yaitu melakukan inovasi, dimana pada tahap ini perusahaan harus membuat ide-ide pelayanan yang baru dan belum pernah ada sebelumnya. PT KAI telah berupaya melakukan beberapa inovasi diantaranya dengan memberikan pelayanan sistem online.

Hasil penelitian ini menunjukkan bahwa pelayanan sistem online ini tidak berpengaruh signifikan terhadap keputusan pembelian tiket kereta api PT KAI di Sumatera Selatan. Hal ini mungkin disebabkan masih terbatasnya pengetahuan masyarakat wilayah Sumatera Selatan tentang pelayanan sistem online tersebut sehingga belum banyak yang bisa memanfaatkan pelayanan yang disediakan secara maksimum. Sebagai contoh, meskipun PT. KAI telah menyediakan RTS New Generation sejak tahun 2016, namun masih banyak masyarakat yang belum mengetahui cara pemesanan makanan yang disediakan oleh sistem tersebut. Hal ini tentunya menyebabkan masyarakat tidak bisa meninkmati pelayanan sistem online yang telah disediakan oleh PT. KAI. Hasil penelitian ini menunjukkan bahwa pelayanan sistem online ini tidak berpengaruh signifikan terhadap keputusan pembelian tiket kereta api PT KAI di Sumatera Selatan. Hal ini mungkin disebabkan masih terbatasnya pengetahuan masyarakat wilayah Sumatera Selatan tentang pelayanan sistem online tersebut sehingga belum banyak yang bisa memanfaatkan pelayanan yang disediakan secara maksimum. Sebagai contoh, meskipun PT. KAI telah menyediakan RTS New Generation sejak tahun 2016, namun masih banyak masyarakat yang belum mengetahui cara pemesanan makanan yang disediakan oleh sistem tersebut. Hal ini tentunya menyebabkan masyarakat tidak bisa meninkmati pelayanan sistem online yang telah disediakan oleh PT. KAI.

Indikator dari pelayanan sistem online yang diantaranya penggunaan aplikasi Paditrain dan Kai Access, kemudahan dalam menggunakan website resmi pembelian tiket online, kepraktisan yang diberikan dalam mencetak tiket online, media yang digunakan dalam pemesanan tiket, serta adanya jaminan keamanan dalam transaksi tiket. Namun ada indikator yang belum maksimal diantaranya kestabilan jaringan yang diberikan pada sistem online, kehandalan mesin tiket online, dan juga server pemesanan tiket online yang masih mengalami gangguan. Hal ini lah yang menyebabkan variabel pelayanan sistem online tidak berpengaruh terhadap keputusan pembelian.

Variabel kedua yaitu promosi, berpengaruh positif signifikan terhadap keputusan pembelian. PT. KAI banyak melakukan promosi baik berupa berita yang bersifat komersial di media cetak, maupun hasil wawancara yang disiarkan dalam media televisi. Oleh karena itu, responden menganggap 
bahwa kegiatan promosi yang sudah dilakukan oleh PT. KAI sudah tepat untuk mengajak masyarakat mengetahui lebih lanjut tentang pelayanan yang dimiliki oleh PT KAI. Sarana promosi yang paling efektif dalam memasarkan transportasi kereta api adalah promosi dari mulut ke mulut. Cara promosi lain yaitu viral marketing dan telah terbukti mempunyai peran besar pada keputusan pembelian konsumen dengan mempengaruhi pilihan konsumen. Teknik ini yaitu sebuah teknik pemasaran yang digunakan untuk menyebarkan sebuah pesan pemasaran dari satu website atau pengguna-pengguna kepada website atau para pengguna lain, yang mana dapat menciptakan pertumbuhan eksponensial yang potensial seperti layaknya sebuah virus.

Tiga tahapan promosi dari mulut ke mulut menurut Sumardi (2009) adalah TAPS (Talking, Promoting, Selling).:

- Membicarakan adalah tahapan dimana seorang konsumen membicarakan sebuah produk atau merek kepada konsumen lain,

- Mempromosikan ketika seorang konsumen bukan hanya sekedar membicarakan merek/produk tapi juga bersedia untuk mempromosikannya kepada konsumen lain,

- Menjual adalah tahapan dimana seorang konsumen mau untuk menjualkan merek/produk tersebut kepada orang lain.

\section{KESIMPULAN}

Hasil penelitian menunjukkan bahwa pelayanan sistem online tidak berpengaruh signifikan terhadap keputusan pembelian, sedangkan variabel promosi berpengarus positif signifikan terhadap keputusan pembelian. Hal ini menunjukkan bahwa alasan utama masyarakat dalam memilih transportasi kereta api di Sumatera Selatan masih dipengaruhi oleh kegiatan promosi baik itu secara mulut ke mulut maupun secara formal. Untuk menarik minat pelanggan baru, PT KAI harus senantiasa melakukan inovasi pelayanan sistem online agar dapat bersaing di pasar.

\section{SARAN}

1 Pelayanan Sistem Online berpengaruh tidak signifikan terhadap Keputusan Pembelian, dengan berpengaruhnya Pelayanan Sistem Online terhadap Keputusan Pembelian maka sebaiknya Pelayanan Sistem Online ditingkatkan agar Keputusan Pembelian meningkat.

2 Promosi berpengaruh secara signifikan terhadap variabel Keputusan Pembelian, dengan demikian Promosi harus ditingkatkan agar Keputusan Pembelian dapat meningkat.

\section{DAFTAR PUSTAKA}

Arikunto, (2010), Metodologi Penelitian, Bandung: CV Alfa Beta.

Cooper, Donald R. dan C. William Emory (1996). Metode Penelitian Bisnis. Edisi 5 Jilid 1. Jakarta: Erlangga. 
Duari, I Putu Hardani Hesti (2014).

Pengaruh Bauran Pemasaran

Terhadap Keputusan Membeli

Tiket Pesawat di Total Nusa

Indonesia Tour and Travel

Yogyakarta. Jurnal Media

Wisata, Vol. 12 No.1 Mei 2014.

Ghozali (2011). Metodologi Penelitian,

Jakarta : PT. Raja Grafindo

Persada

Gustafsson, A. \& Johnson, M.D.

(2003). Competing in a Service

Economy : How to Create a

Competitive Advantage through

Service Development and

Innovation. (1st edn.). San

Fransisco: Jossey-Bass.

Jati (2012), Pengukuran Tingkat Keputusan pembelian tiket. Jakarta: Rineka Cipta.

Kotler (2013). Manajemen Pemasaran-

Analisis Perilaku Konsumen.

Yogyakarta: BPFE.

Purwanto dan Sulistyastuti (2016), Metodologi Penelitian.

Jakarta: Ghalia Indonesia

Sudjana (2010) Metode Penelitian Kuantitatif, Kualitatif Dan

$R \& H$, Alfabeta Bandung

Sugiyono. (2013). Metodologi

Penelitian, PT. Raja Grafindo

Persada Jakarta.
Sumardi (2009). Word of Mouth Marketing. Fans dan Peluang Tumbuh. SWA, 09/XXV, 30 April-13 Mei.

Undang-Undang No 23 tahun 2007 tentang Transportasi Kereta Api.

Wardhana, Aditya, dan Kartawinata, Rustandi (2016). The Determinants of Indonesian Railway Online Ticketing Servuces in Indonesia. International Journal of Science and Research Vol. 5 No. 7, July 2016.

Wasiun, R., Nugraha, Hari Susanta, dan Prabawani, Bulan (2015). Pengaruh Pelayanan Sistem Online, Tarif, dan Publikasi Terhadap KeputusanPembelian Secara Online Tiket Kereta Api Relasi Semarang - Jakarta (Studi Kasus Pada PT.Kereta Api Indonesia DAOP IV Semarang Tawang). Diponegoro Journal Of Social And Political Of Science Tahun 2015.

www.bps.go.id. Jumlah Penumpang Kereta Api，2006-2017 (Ribu Orang). Diakses 20 Februari 2017.

www. kai.id (diakses 16 Februari 2017) 